Nordisk Tidsskrift for Kriminalvidenskab 2006

\title{
FORVARING OG UTVIKLINGEN FOR PERIODEN 2002-2006
}

Av forsker Berit Johnsen og Jurist Birgitte Langset Storvik

In Norway, a new law on preventive detention took effect on January 1, 2002. The purpose of the law is to protect the public from offenders who are considered to be dangerous. In principle, there is no upper time limit to a sentence of preventive detention. However, when the court sentences a person to preventive detention, it has to set a time frame which cannot exceed 21 years. The court can prolong the sentence at a later date if it considers the convicted person still too dangerous for release.

This study focuses on legal usage with respect to the new law on preventive detention. During the four years since the law came into effect, the courts have passed 107 sentences of preventive detention. Six of these sentences have been applied to women. The study shows that more sentences of preventive detention have been passed than one should expect. Preventive detention is primarily used to punish serious offences like murder and sexually related crimes. So far, 31 persons have been released or released on parole from preventive detention. According to current regulations, a person can be released on parole from preventive detention when he or she is no longer considered a danger to the public. In other words, persons serving preventive detention have to change during imprisonment. Legal practice sometimes differs from the regulations in this matter, and some prisoners have been released on parole based on a court ruling that the prison has nothing more to offer them in terms of possibilities for change. So far, two persons have had their sentences prolonged by two years."

\section{Innledning}

Forvaring har eksistert som straffereaksjon i Norge siden 1. januar 2002. Særreaksjonen erstatter sikring i saker der domfelte ble ansett for å være tilregnelig i gjerningsøyeblikket. ${ }^{1}$ Bakgrunnen for innføring av den nye straffen var at sikringsinstituttet under hele sin eksistens ble utsatt for sterk kritikk. Dette gjaldt både i forhold til innhold og regelverk.

Av de andre landene i Norden er det bare Danmark som har en forvaringsordning som til en viss grad kan sammenlignes med den norske. Når det gjelder vilkår for å bli idømt forvaring er de norske og danske bestemmelsene ganske like. De anvendes imidlertid forskjellig, mest sannsynlig fordi Danmark har livstidsstraff som idømmes i de mest alvorlige tilfellene.

\footnotetext{
* Title in English: Trends in the Use of Preventive Detention 2002-2005. Orginal in Norwegian.
} 
Forvaring er en tidsubestemt straff som har til hensikt å beskytte samfunnet mot de lovbryterne som blir vurdert til å være de farligste. Grunnvilkåret for å benytte reaksjonen er at en tidsbestemt straff ikke anses tilstrekkelig til å verne samfunnet, jf. straffeloven $\S 39 \mathrm{c}$. Det er samfunnsvernet som skal begrunne reaksjonen, ikke rettferdighetstankegangen. Dersom en ordinær fengselsstraff anses tilstrekkelig, kan det ikke forsvares å idømme lovbryteren den tilleggsbelastning en tidsubestemt straff innebærer.

\section{Historikk}

Veien frem til dagens bestemmelser om særreaksjoner har vært lang. Ingen endringer i straffeloven de siste tiår har tatt så lang tid og vært så omdiskutert som denne (Slettan/Øie 1999). Straffelovrådet fikk allerede i 1957 i mandat å vurdere om den daværende sikrings- og forvaringsordningen burde endres, og første utredning ble fremlagt i $1973 .{ }^{2}$ Forslaget møtte sterk kritikk under høringen, og det ble derfor aldri fremmet noe lovforslag på bakgrunn av utredningen. Arbeidet med lovrevisjonen fortsatte, og i 1983 kom Straffelovkommisjonen med en delutredning, ${ }^{3}$ som i stor grad støttet forslaget fra 1973. Også denne utredningen møtte til dels sterk kritikk. I 1985 ble det derfor oppnevnt et utvalg som skulle vurdere særreaksjonene på nytt - Scerreaksjonsutvalget. Utvalget avga sin utredning $\mathrm{i}$ 1989. ${ }^{4}$ Med utgangspunkt i denne, fremmet Justisdepartementet endelig forslag. til nye bestemmelser sommeren $1994 .^{5}$ Pga. uenighet i forhold til særreaksjon for psykisk utviklingshemmede, ble forslaget vedtatt i to omganger. Særreaksjonene om overføring til tvungent psykisk helsevern og forvaring ble vedtatt i lov av 17. januar $1997 \mathrm{nr} .11,{ }^{6}$ mens særreaksjonen tvungen omsorg først ble vedtatt i lov av 15. juni $2001 \mathrm{nr}$. $64 .^{7}$ Samtidig ble det vedtatt endringer av forvaringsbestemmelsen. Alle endringene trådte i kraft 1 . januar $2002 .^{8}$

\section{Antall forvaringsdommer}

Per 21. mars 2006 er det avsagt 107 forvaringsdommer som på dette tidspunktet er rettskraftige. Av disse er 45 konverterte dommer, det vil si sikringsdommer som ikke var avsluttet per 1. januar 2002, og som av retten er blitt omgjort til forvaringsdommer.

Konvertering kan skje etter begjæring av domfelte selv eller av påtalemyndigheten, avhengig av om sikringstiltaket var iverksatt eller ikke, jf. overgangsreglene. ${ }^{9}$ Flere sikringsdømte har benyttet seg av denne muligheten med håp om eventuell innstilling av sikringstiltaket eller en mildere forvaringsdom. Hvis statsadvokaten mener at særreaksjon fortsatt er nødvendig etter at sikringstiden utløper, må saken uansett bringes inn for retten for omgjøring. 
Fremdeles er det 15 personer som per 21. mars 2006 gjennomfører en sikringsdom. Fem sitter i fengsel, mens 10 er under tilsyn av friomsorgen. For noen er det varslet konverteringssak med påstand om idømmelse av forvaring. Vi finner flere tilfeller der konverteringsspørsmålet ikke er avklart når lengstetiden for sikringen er nådd. Den sikringsdømte er da i prinsippet å betrakte som løslatt, men siden hverken den sikringsdømte selv eller kriminalomsorgen vet om statsadvokaten vil reise tiltale om konvertering, oppstår det et slags "vakuum av uvisshet". Dette er uheldig, noe som også kommenteres i dommene.

Tabell 1. Antall avsagte forvaringsdommer per år fordelt etter om de er nye eller koverterte.

\begin{tabular}{|c|c|c|c|}
\hline Dom avsagt & Totalt & Antall nye forvaringsdommer & Antall konverterte dommer \\
\hline 2002 & 22 & 15 & 7 \\
\hline 2003 & 38 & 17 & 21 \\
\hline 2004 & 21 & 10 & 11 \\
\hline 2005 & 24 & 19 & 5 \\
\hline 2006 pr. 21. mars & 2 & 1 & 1 \\
\hline Totalt & $\mathbf{1 0 7}$ & $\mathbf{6 2}$ & $\mathbf{4 5}$ \\
\hline
\end{tabular}

Vi kan ikke regne med særlig mange flere konverteringsdommer. Med tanke på hvor mange som vil bli dømt til forvaring i tiden fremover, er det mest interessante i denne tabellen antall nye forvaringsdommer (ikke-konverterte) som er avsagt hvert år. Den mest naturlige sammenligningskilden er antall deldommer ${ }^{10}$ som ble avsagt per år i sikringsinstituttet. Vi har tatt utgangspunkt i perioden 1992 til 2001 hvor det ble avsagt fra 18 til 43 deldommer per år. ${ }^{11}$ Vi ser at årlig antall nye forvaringsdommer til og med 2005 ligger i underkant av eller såvidt over det laveste antall deldommer som ble avsagt $\mathrm{i}$ de siste ti årene sikringen eksisterte.

\section{Domstol}

De fleste, nærmere bestemt 60 , av forvaringsdommene er endelig avgjort i tingretten. Trettisyv saker er avgjort i lagmannsretten, mens ti av forvaringsdommene er avgjort i Høyesterett. Det viser seg at det er de mest alvorlige sakene som behandles av flere instanser. Seks av dommene som er avgjort i Høyesterett, gjelder drap. Vi ser også at mens tre av fire konverteringsdommer er avgjort i tingretten, er over halvparten av nye forvaringsdommer (ikke-konverterte) avgjort i høyere instanser. Bare én av de ti høyesterettsdommene som har endt med forvaring, har vært en konverteringssak. 


\section{Hvem er de forvaringsdømte?}

Kjønn

Av de 106 forvaringsdømte er 100 menn og seks kvinner (én mann har blitt dømt til forvaring to ganger), For de 69 personene som per 21. mars 2006 gjennomfører forvaringsstraff i fengsel, er kvinneandelen 5,8 prosent. Kvinneandelen generelt blant innsatte denne datoen er 5,3 prosent. $^{12}$

Før innføringen av forvaringsstraffen vurderte departementet om kvinnelige forvaringsdømte skulle gjennomføre straffen på Ila sammen med mannlige forvaringsdømte. Ila ble opprettet som forvaringsanstalt etter at den såkalte "Gråsoneanstalten" ble lagt på is. ${ }^{13}$ I forarbeidene ble det imidlertid uttalt at kvinnelige forvaringsdømte i første omgang skulle få et eget tilbud på Bredtveit kvinnefengsel, fordi man antok at andelen kvinnelige forvaringsdømte ville bli lav i den første perioden etter bestemmelsens inntreden. Føringene sier imidlertid at dette tilbudet bare skal bestå inntil de kvinnelige forvaringsdømte "... utgjør et antall som gjør det hensiktsmessig med en kvinneavdeling på Ila". ${ }^{14}$ I senere tid har dette antallet blitt oppgitt til å være fem. ${ }^{15}$ Bredtveit har en periode hatt fem forvaringsdømte, men er nå nede i fire.

\section{Alder}

Gjennomsnittsalderen på de forvaringsdømte er 41 år. Den eldste er 68 år, mens den yngste er 22 år. Alderen på de forvaringsdømte har flyttet seg noe oppover siden forrige undersøkelse i 2003 (Johnsen, 2003a), og i dag finner vi flest forvaringsdømte i aldersgruppen 40- 49 år. Det virker som om domstolene er tilbakeholdne med å idømme forholdsvis unge personer forvaring. En Høyesterettsdom stadfester dette i en konverteringssak hvor tiltalte $i k k e$ ble dømt til forvaring blant annet på grunn av sin unge alder (20 år). ${ }^{16}$

\section{Statsborgerskap}

96 av de forvaringsdømte er norske statsborgere. Fire er fra andre nordiske land, mens seks er fra land utenfor Norden. To av de nordiske statsborgerne er overført til fortsatt straffegjennomføring i sine respektive hjemland. Av de forvaringsdømte som per 21. mars 2006 sitter i norske fengsler, er 11,5 prosent utenlandske statsborgere. Dette ligger under den prosentvise andelen av utenlandske statsborgere i fangebefolkningen for øvrig denne datoen som er på ca. 16,6 prosent.

\section{Type lovbrudd}

For å bli dømt til forvaring må lovbryteren ha begått eller forsøkt å begå en forbrytelse som har krenket andres liv, helse eller frihet - vårt samfunns fundamentale rettsgoder. ${ }^{17}$ Eksempler på slike forbrytelser kan være drap, vold, seksualforbry- 
telser, ildspåsettelse, trusler og ran. Vinningsforbrytelser faller utenfor. Narkotikaforbrytelser vil heller ikke falle inn under forvaringens anvendelsesområde, selv om dette indirekte kan sies å krenke andres helse. ${ }^{18}$

\section{Hovedlovbrudd}

De aller fleste som blir dømt til forvaring har overtrådt flere bestemmelser i straffeloven. Vi har registrert "hovedlovbruddet", det vil si det lovbruddet som anses som det mest alvorlige. Ut fra tabell to ser vi at de lovbruddene som først og fremst fører til forvaring, er drap og seksualforbrytelser. Flere av seksualforbrytelsene omfatter både voldtekt og sedelighet. Når det gjelder drap vil vi poengtere at det totale antallet på 33 inkluderer både drap og drapsforsøk. Hovedlovbruddet som forekommer mest hos kvinnene (tre av seks) er legemsbeskadigelse. Ingen av kvinnene er dømt for seksualforbrytelser.

Tabell 2. Antall forvaringsdommer fordelt etter type lovbrudd.

\begin{tabular}{|l|c|}
\hline Type lovbrudd & Antall \\
\hline Drap & 33 \\
\hline Sedelighet & 24 \\
\hline Voldtekt & 24 \\
\hline Legemsbeskadigelse & 9 \\
\hline Brannstiftelse & 4 \\
\hline Trusler & 5 \\
\hline Ran & 5 \\
\hline Skadeverk & 3 \\
\hline Total & $\mathbf{1 0 7}$ \\
\hline
\end{tabular}

Sammenligner vi hovedlovbruddene i konverteringsdommene med de nye forvaringsdommene (ikke-konverterte) ser vi at fordelingen er svært lik. Så langt er det i all hovedsak de samme lovbruddene som fører til forvaring som i sin tid førte til sikring. Det var også dette man forutså på Ila (Ila fengsel og sikringsanstalt 2001, Johnsen 2003b).

\section{Alvorlig eller mindre alvorlig forbrytelse}

Bestemmelsen om forvaring skiller mellom alvorlige forbrytelser ( $§ 39 \mathrm{c} \mathrm{nr.} 1)$ og mindre alvorlige forbrytelser ( $§ 39 \mathrm{c} \mathrm{nr}$. 2). Vilkårene er strengere for å bli dømt etter nr. 2. Hvor grensen trekkes mellom de to alternativene beror på domstolenes skjønn og utvikling i praksis. ${ }^{19}$ 
101 av forvaringsdommene er idømt på grunnlag av alvorlige forbrytelser (nr. 1), mens seks gjelder mindre alvorlige forbrytelser (nr. 2). Forvaringsdommer etter nr. 2 er avsagt i saker som har omhandlet skadeverk, legemsbeskadigelse, ${ }^{20}$ sedelighet, ${ }^{21}$ trusler og ran.

Alle som er idømt forvaring etter nr. 2 har tidligere begått eller forsøkt å begå liknende alvorligere forhold. Dette stilles også som vilkår, mens det ikke er et vilkår for nr. 1. Etter loven slik den ble vedtatt i 1997, kunne en person ikke bli dømt til forvaring uten at han eller hun tidligere hadde begått eller forsøkt å begå en forbrytelse som rammes av bestemmelsen. Dette vedtaket var i tråd med anbefalingene i forarbeidene. Departementet foreslo imidlertid rett før Stortinget skulle vedta ikrafttredelsen av særreaksjonene, at forvaring kunne idømmes på grunnlag av ett lovbrudd. De mente at enkelte lovbrytere allerede etter å ha begått én alvorlig forbrytelse hadde vist en så farlig atferd at det av hensyn til beskyttelsen av samfunnet måtte kunne reageres med forvaring dersom tidsbestemt straff ikke ble ansett som tilstrekkelig. ${ }^{22}$ Departementet erkjente at en slik lovendring ville føre til noen flere forvaringsdømte, men at det ikke innebar noen utvidelse av anvendelsesområdet for daværende regler om sikring av tilregnelige lovbrytere. Det er til nå 22 personer som er dømt til forvaring etter nr. 1 uten at de tidligere har vært domfelt.

\section{Farevurderinger}

Farevurderingen er det mest omdiskuterte punktet i spørsmålet om idømmelse av forvaring. Ved alvorlige forbrytelser (nr. 1) må det foreligge en "nærliggende fare" for at vedkommende igjen vil begå en alvorlig forbrytelse som nevnt $\mathrm{i}$ bestemmelsen om forvaring. Dette innebærer at faren må være "kvalifisert og på domstidspunktet vurderes som reell". ${ }^{23}$ Ved mindre alvorlige forbrytelser (nr. 2) er kravet skjerpet ved at faren for tilbakefall må være "særlig nærliggende", og det må være "nær sammenheng mellom den tidligere og den nå begåtte forbrytelsen".

Det er vanskelig å vurdere om det foreligger en fare for tilbakefall på det tidspunktet dommen skal avsies. Likeledes er det vanskelig å vurdere hvor lenge tiltalte vil måtte anses som farlig. Selv om man prøver å standardisere farevurderingene, vil de uansett være gjenstand for ulike grader av skjønn. Momenter som tillegges vekt er blant annet alvorlighetsgraden av lovbruddet som er begått, lovbryterens sosiale tilhørighet, forhold til rusmidler og seksualitet samt den psykiske helsetilstand. I tillegg understrekes det i nr. 1 at det særlig skal legges vekt på eventuelle tidligere begåtte lovbrudd som kunne medført forvaring.

Det er retten som avgjør i hvilken grad det foreligger fare for tilbakefall og utmåler straffen ut fra det. En sikringsdom forutsatte uttalelser fra psykiatrisk sakkyndige til dette formålet. Bruk av rettspsykiatriske undersøkelser har vært et av de mest omstridte områdene i utarbeidelsen av bestemmelsene om særreaksjonene. 
Spesielt har diskusjonen dreid seg om psykiatriske vurderinger av tilregnelige lovovertredere, det vil si de som kan bli idømt forvaring. Hverken Straffelovrådet eller Særreaksjonsutvalget gikk inn for at det måtte foreligge en rettspsykiatrisk erklæring for å kunne idømme forvaring. Særreaksjonsutvalget ville gå lenger enn Straffelovrådet i å redusere psykiatriens medvirkning. De mente at prediksjon av gjentakelsesfare først og fremst måtte bedømmes på grunnlag av objektive omstendigheter som tidligere atferd og kriminalitet, aktuell kriminalitet osv., og at psykiaterne derfor ikke hadde bedre forutsetninger enn påtalemyndighet og domstoler for å vurdere tilbakefallsfaren. ${ }^{24}$

I den endelige bestemmelsen om forvaring er psykiatriens medvirkning ytterligere redusert. Kravet er at det skal foretas en personundersøkelse utført av friomsorgen, men at denne kan erstattes av en rettspsykiatrisk undersøkelse. ${ }^{25}$ Praksis så langt viser at syv forvaringsdommer er avsagt hvor det kun forelå personundersøkelse. Av de 98 sakene det foreligger rettspsykiatriske uttalelser, er det flere hvor det også foreligger en personundersøkelse. To konverteringsdommer er avsagt uten at det ble foretatt hverken en personundersøkelse eller rettspsykiatrisk undersøkelse i forbindelse med dommen.

I tillegg ser vi at det i 30 av 37 lagmannsrettsdommer ble benyttet to eller flere sakkyndige. Bruk av mer enn én psykiatrisk sakkyndig er også tilfelle i de aller fleste tingrettsdommene. ${ }^{26}$ Loven stiller $i k k e$ krav om at det skal være flere sakkyndige i samme sak. ${ }^{27}$ Riksadvokaten antar imidlertid at de sakene der påtalemyndigheten mener det bør brukes psykiatrisk sakkyndige normalt sett er så kompliserte at det bør oppnevnes to. ${ }^{28}$ Likeledes anbefaler den rettsmedisinske kommisjon at det alltid brukes to sakkyndige. Disses råd synes å bli fulgt i de aller fleste saker som angår forvaring.

Ut fra dette er det tydelig at forarbeidenes antakelser om at bruken av rettspsykiatrisk sakkyndige ville bli betydelig redusert, så langt ikke er tilfelle. ${ }^{29}$ Sakkyndige blir brukt nesten like mye som under sikringsinstituttet (se også Nilson 2005).

Rettspsykiaternes vurderinger blir mer eller mindre utførlig referert i dommen, og ut fra dette skulle det være rimelig å anta at de blir tatt hensyn til når endelig dom avsies. I hvilken grad de blir vektlagt er det imidlertid vanskelig å si noe om, noe som også understøttes av Nilson (2005) som har foretatt en nærmere analyse av dette forholdet.

Forvaringsbestemmelsen er en "kan-regel", jf. straffeloven § 39 c. Det betyr at det er opp til retten å avgjøre om forvaring skal idømmes dersom vilkårene er oppfylt. Rieber-Mohn (2003) hevder at denne friheten har en begrenset realitet. Han mener at vilkårene for forvaring er utformet slik at når disse er oppfylt, tilsier normalt viktige samfunnsmessige hensyn at forvaring idømmes. Høyesterett har også uttalt at i de fleste tilfellene der vilkårene ellers er til stede, vil det neppe være grunnlag for å unnlate å idømme forvaring. ${ }^{30}$ 


\section{Tidsramme og minstetid}

Selv om forvaring er en tidsubestemt straff, fastsetter retten alltid en tidsramme som vanligvis ikke bør overstige 15 år og ikke kan overstige 21 år. Betydningen av tidsrammen er i første rekke at all løslatelse før utløpet av denne skal skje på prøve. Tidsrammen utgjør også en rettssikkerhetsgaranti ved at reaksjonen vil opphøre hvis påtalemyndigheten ikke innen tre måneder før forvaringstidens utløp reiser sak for retten om forlengelse. Høyesterett har uttalt at tidsrammen også kan ha en symbolsk og psykologisk virkning overfor allmennheten, for den dømte selv og for en domstol som senere skal avgjøre saken om prøveløslatelse. ${ }^{31}$

Retten fastsetter i de fleste forvaringsdommene også en minstetid, som ikke kan overstige ti år. Minstetiden har betydning for når den forvaringsdømte tidligst kan bli prøveløslatt. Fastsetter retten ikke minstetid, kan domfelte søke om prøveløslatelse ett år etter at forvaringsdommen er rettskraftig. Minstetid skal i første rekke fastsettes når hendelsens grovhet og omstendighetene ellers tilsier at det kan virke støtende på den allmenne rettsfølelse om prøveløslatelse skjer kort tid etter forgåelsen. ${ }^{32}$ Høyesterett har uttalt at fastsettelse av minstetid kan være hensiktsmessig i forhold til innsattes rehabilitering. De har imidlertid understreket at forvaring ikke skal begrunnes ut ifra den enkeltes utbytte av gjennomføringen. ${ }^{33}$

Den politiske behandlingen av særreaksjonene medførte en utvidelse av både tidsrammen og minstetiden utover det som opprinnelig ble foreslått $i$ forarbeidene. Både Straffelovrådet og Særreaksjonsutvalget foreslo i sine innstillinger at tidsrammen skulle være maksimalt 15 år. Likeledes mente de at minstetiden ikke måtte overskride fem år. Da Justiskomiteen i desember 1996 drøftet Justisdepartementets endelige forslag til nye bestemmelser, ble det et politisk flertall for å heve grensen for både tidsramme og minstetid. Begrunnelsen var at "en dom på forvaring ikke kunne være kortere enn den tiden en annen som blir dømt for en tilsvarende forbrytelse må sone i fengsel før prøveløslatelse kan skje". ${ }^{34}$

\section{Tidsrammen}

Ser vi på statistikken over tidsrammen finner vi følgende:

Tabell 3. Antall forvaringsdommer fordelt etter lengden av tidsrammen.

\begin{tabular}{|c|c|}
\hline Tidsrammen $^{*}$ & Antall dommer \\
\hline $1-5 \mathrm{a} r$ & 48 \\
\hline $6-8 \mathrm{a} \mathrm{r}$ & 25 \\
\hline $9-15 \mathrm{a} \mathrm{r}$ & 25 \\
\hline $16-21 \mathrm{a} \mathrm{r}$ & 9 \\
\hline
\end{tabular}

* Vi gjør oppmerksom på at tidsrammen alltid settes som et eksakt tall, for eksempel tre år.

I tabellen har vi gruppert alle dommene innunder bestemte tidsspenn. 
Av tabellen ser vi at 48 dommer har tidsrammer på under fem år. Det er $\mathrm{i}$ denne kategorien vi finner de fleste konverteringsdommene. Av de 48 er hele 29 konverteringsdommer. Konverteringsdommer med lav tidsramme er ofte blitt målt ut fra hvor lenge det er igjen av sikringen.

Når det gjelder av tidsrammen har Høyesterett uttalt at det ikke kan være riktig å prøve å komme frem til noe bestemt forhold mellom tidsramme og alternativ fengselsstraff som skal gjelde generelt. Forholdstallet bør kunne variere, der det også kan ha betydning om det er snakk om en kort eller en særlig lang alternativ fengselsstraff. ${ }^{35}$ Vår gjennomgang av dommene viser imidlertid at flere dommere ser hen til hva straffeutmålingen for ordinær fengselsstraff ville ha vært for den aktuelle forbrytelsen selv om det er hensynet til samfunnsvernet som skal bestemme tidsrammen. En gjennomgang av Høyesterettsdommene viser at tidsrammene i alle tilfellene utenom ett, ${ }^{36}$ er i samsvar med, eller ligger litt høyere enn alternativ fengselsstraff. $\mathrm{Vi}$ antar at denne tendensen gjenspeiler seg $\mathrm{i}$ underinstansenes avgjørelser.

Dette kommer også til uttrykk i forhold til hvilke lovbrudd vi finner i de to laveste kategoriene. Alle forvaringsdommene på skadeverk og legemsbeskadigelse har tidsrammer opp til fem år. Dommene på både trusler og ran har tidsrammer fra tre til åtte år. De aller fleste sedelighetsdommene har tidsrammer fra to til åtte år, mens hovedtyngden av voldtektsdommer ligger noe over med tidsrammer fra fem til ti år.

Det er 25 dommer som har en tidsramme fra ni til 15 år. Disse er stort sett ilagt for drap, men også for voldtekt. Tidsrammer utover "bør-grensen" på 15 år er gitt i ni tilfeller. Alle disse gjelder drap. Minstetiden er for samtlige satt til ti år. Det er altså ni dommer som sprenger grensene for hva Straffelovrådet og Særreaksjonskommisjonen foreslo som grenser på både tidsramme og minstetid. I to av disse dommene er det heller ikke bevist at lovbryteren tidligere har begått eller forsøkt å begå alvorlig kriminalitet. Etter det opprinnelige lovvedtaket kunne ikke de blitt dømt til forvaring.

\section{Minstetid}

Lengden på minstetiden skal settes med utgangspunkt $\mathrm{i}$ et anslag over når prøveløslatelse etter en tidsbestemt fengselsstraff kunne skjedd. ${ }^{37}$ En gjennomgang av høyesterettsdommene viser at praksis er i samsvar med dette. Det er rimelig å anta at også underinstansene forholder seg til dette. Minstetid er fastsatt i 68 av forvaringsdommene. Lengden strekker seg fra ett til ti år. I 13 av dommene er det satt en minstetid på ti år (lovens høyeste). Alle disse sakene gjelder drap. I de fleste voldtekt- og sedelighetssaker hvor det er satt minstetid, er den satt mellom to og fire år. 
I 39 dommer har domstolen ikke satt noen minstetid. Hele 35 gjelder konverteringsdommer. Grunnen til at så mange konverteringdommer er avsagt uten minstetid, må være at domfelte i disse tilfellene har gjennomført to tredjedeler av hva en alternativ fengselsstraff ville vært. Tidspunktet for prøveløslatelse er derfor allerede inne.

\section{Innhold i forvaringsstraffen}

I tillegg til at forvaring skal være en reaksjon på en allerede begått forbrytelse, skal den også være et middel for å hindre lignende forbrytelser i fremtiden. Dette oppfylles på to måter. For det første hindrer fengslingen lovbryteren $\mathrm{i}$ å begå nye lovbrudd. For det andre blir det under gjennomføringen av forvaringsdommen fokusert på endring. I forarbeidene legges det til grunn at forvaringsdommer skal ha et annet innhold enn vanlig fengselsstraff. Det stilles også krav til tverrfaglig behandlingsinnsats og høy bemanningsfaktor. ${ }^{38}$ Man har på begge forvaringsanstaltene - Ila og Bredtveit - lagt mye arbeid i å utvikle og tilrettelegge et tilbud for de forvaringsdømte. Metoder som benyttes er blant annet miljøarbeid/terapi, programvirksomhet, samtalegrupper, skole/utdanning, arbeidstrening, fritidsaktiviteter og individuell behandling. Dette er en blanding av tradisjonelle virkemidler i straffegjennomføringen slik som skole/utdanning og arbeid, og mer spesifikke tilrettelagte tilbud for de forvaringsdømte slik som en del påvirkningsprogrammer, samtalegrupper og individuell behandling (Ila fengsel, forvarings- og sikringsanstalt 2002).

\section{Løslatelse og forlengelser}

Løslatelse fra forvaring skal skje når vedkommende ikke lenger utgjør en fare for samfunnet. I følge kommentarer til forskriften om forvaring er det endring som skal til for at den forvaringsdømte skal kunne bli løslatt. ${ }^{39}$ Selv om fengslene arbeider grundig med å dokumentere endring, ser vi at sakkyndigevurderinger i stor grad også trekkes inn i spørsmålet om løslatelse, selv om loven ikke krever dette. Uansett er det ikke til å komme bort fra at skjønn spiller en rolle ved farevurderingene også i spørsmålet om løslatelse.

Løslatelse før forvaringstidens utløp (tidsrammen) skal skje på prøve. Prøveløslatelse kan innvilges av kriminalomsorgen hvis innsatte krever seg prøveløslatt og påtalemyndigheten og kriminalomsorgen er enige om at det er forsvarlig å prøveløslate vedkommende. Er det uenighet i spørsmålet, kan domfelte forlange å få prøvet saken for retten. Blir prøveløslatelsen avslått av retten, har han/hun krav på å få prøvet saken på ny ett år etter at denne dommen er rettskraftig. ${ }^{40}$

Ved prøveløslatelse fra forvaring blir det fastsatt en prøvetid fra ett til fem år. ${ }^{41}$ I prøvetiden kan det settes vilkår som ved betinget dom, ${ }^{42}$ for eksempel krav om bestemt oppholdssted, alkohol-/rusforbud, gjennomføring av behandling 
eller institusjonsopphold. Møteplikt for friomsorgen kan settes som vilkår ved prøveløslatelse fra retten, og skal settes som vilkår ved prøveløslatelse av kriminalomsorgen. ${ }^{43}$ Så langt vi har klart å ta rede på, har samtlige prøveløslatte hittil fått oppfølging av friomsorgen. ${ }^{44}$

Vi ser allerede nå at en rekke forvaringsdømte har fått prøvet saken om prøveløslatelse. Vi vet også at det vil bli et stort antall slike saker i nær fremtid, fordi det er mange som snart har oppnådd tidspunkt for mulig prøveløslatelse. Dette gjelder ikke minst de med konverteringsdom hvor retten ikke har satt minstetid. Per 21. mars 2006 var det 24 prøveløslatte fra forvaring. Én person har vart prøveløsladt og satt på dette tidspunkt i varetekt i påvente av dom på gjeninnsettelse til forvaring, på grunn av gjentalte brudd på vilkår i prøvetiden. På samme tidspunkt var det sju løslatte. Seks av de sju har vært prøveløslatt før de ble endelig løslatt, og alle ble løslatt ved tidsrammens utløp. Én forvaringsdømt gikk ikke veien om prøveløslatelse, men ble løslatt ved sikringens utløp.

Ser vi nærmere på de 31 som er eller har vært prøveløslatt, var 13 under sikring i frihet da spørsmålet om omgjøring til forvaring kom opp for retten. Alle disse ble umiddelbart prøveløslatt i konverteringsdommen. Det samme gjaldt seks sikringsdømte som satt fengslet da konverteringssaken kom opp for retten. Seks forvaringsdømte har blitt prøveløslatt fra fengsel av kriminalomsorgen, mens seks andre har blitt prøveløslatt av retten. Det er ikke vanskelig å forestille seg at kriminalomsorgen er restriktive i spørsmål om prøveløslatelse. De føler nok et større ansvar enn retten for at den prøveløslatte ikke skal begå nye lovbrudd.

Når tidsrammen utløper, kan lovbryteren vurderes på nytt av retten. Hvis domstolen konkluderer med at gjentakelsesfaren fremdeles er til stede, kan tidsrammen forlenges med inntil fem år om gangen. Denne adgangen ble også utvidet ved Justiskomiteens behandling av særreaksjonene. ${ }^{45}$ Straffelovrådet gikk inn for tre års forlengelse, mens Særreaksjonsutvalgets forslag var at forlengelse bare kunne skje med to år om gangen. ${ }^{46}$ Det er ingen øvre grense for hvor mange ganger domstolen kan forlenge tidsrammen. To personer har hittil fått forlenget forvaringsdommen, begge med to år. ${ }^{47}$

\section{Forvaring så langt, noen problemstillinger og mulige fremtidstendenser}

Det er gjort få forsøk på å estimere omfanget av forvaring i forarbeidene, mest sannsynlig fordi dette har vært vanskelig å beregne. ${ }^{48}$ Under forarbeidene var man ganske sikker på at antallet ville bli mindre enn deldommene under sikringsinstituttet. ${ }^{49}$ At man per 21. mars 2006 har 107 rettskraftige forvaringsdommer, er nok likevel over det man så for seg før loven trådte i kraft. Det er flere årsaker til dette, blant annet er det mange konverteringsdommer. Sett i forhold til de to politiske endringene mot slutten av revideringsprosessen - muligheten for å idømme 
forvaring på grunnlag av én alvorlig forbrytelse og utvidelse av tidsrammen - har også disse helt klart medført en utvidet bruk av forvaringsordningen enn det man opprinnelig tenkte. Vi vil nevne at det er interessant i seg selv at vi fikk disse store endringene uten noen form for diskusjoner utenfor den politiske behandlingen helt på tampen av en nesten 50 år lang og til tider stormfull revideringsprosess.

Man visste at muligheten for å idømme forvaring på grunnlag av én alvorlig forbrytelse ville føre til at noen flere kunne bli dømt. Så langt utgjør slike saker 21 prosent av det totale antallet forvaringsdømte. Denne prosentandelen er nesten den samme som statistikkoversikten for 2003 viste (se Johnsen. 2003a). Det skal bli interessant å se om den vil holde seg på dette nivået fremover.

I hvilken grad man så for seg en økning av antall forvaringsdømte på grunnlag av utvidelsen av tidsrammen er uvisst. Med bakgrunn i vilkåret om at "Når en tidsbestemt straff ikke anses tilstrekkelig for å verne samfunnet" mente Særreaksjonsutvalget på prinsipielt grunnlag at forvaringens anvendelsesområde fortrinnsvis burde være i saker hvor alternativet var en kortere eller mellomlang tidsbestemt fengselsstraff. I tilfeller der den tidsbestemte alternative fengselsstraffen ville være av lang varighet, ville den gi tilstrekkelig samfunnsvern. ${ }^{50}$ Hvis tidsrammen på 15 år fikk bestå, ville påtalemyndigheten mest sannsynlig vært tilbakeholden med å påstå forvaring for de mest alvorlige lovbruddene. ${ }^{51}$ Uten de to politiske endringene ville antall forvaringsdommer vært redusert med litt over en fjerdedel.

Det høye antallet forvaringsdømte har medført at Ila er i ferd med å gå utover det antallet på 60 forvaringsplasser som anstalten ble bedt om å opprette. Det ble imidlertid tatt forbehold om at det kunne bli nødvendig å øke kapasiteten på sikt. At behovet for flere plasser allerede skulle oppstå før det var gått fire år, var nok raskere enn antatt. På grunn av at det er blitt avsagt en god del konverteringsdommer hvor minstetiden er satt lavt eller hvor det ikke er satt noen minstetid, er det imidlertid rimelig å anta at det blir en god del prøveløslatelser i tiden fremover. Dette kan igjen medføre store utfordringer for friomsorgen. På den annen side er det forholdsvis mange som har fått lange tidsrammer og lang minstetid, og som vil bli værende i fengsel ganske lenge.

Et annet spørsmål når det gjelder kapasitet er om antallet forvaringsdømte fengslede kvinner noen gang vil overstige grensen på fem. Dette er høyst usikkert. Hvis det totale antallet fengslede forvaringsdømte øker ytterligere, og hvis prosentandelen kvinner holder seg på mellom fem og seks prosent, går man over grensen. Nå viser det seg imidlertid at det var stor variasjon på antall fengslede kvinnelige sikringsdømte i de siste ti årene av sikringsinstituttet. På det minste var det to, og på det meste var det sju. ${ }^{52}$ Spørsmålet er om det vil bli like stor variasjon i antall forvaringsdømte kvinner. Uavhengig av hvor mange fengslede forvaringsdømte kvinner det vil bli i fremtiden, 
må kvinnene få gjennomføre straffen i det fengselet som har det best tilrettelagte tilbudet for denne gruppen. Etter vår oppfatning vil dette være Bredtveit som har lang erfaring med kvinnelige sikringsdømte. Etter hvert har de også opparbeidet kunnskap og erfaring om kvinnelige forvaringsdømte, ikke minst i forhold til hvordan de skal skreddersy løsninger som møter de forvaringsdømte kvinnenes behov.

Når det gjelder type forbrytelser, har vi konstatert at det $\mathrm{i}$ all hovedsak er alvorlige forbrytelser som medfører forvaring. Slik vil det også antakeligvis bli i fremover. Rettspraksis vil etter hvert trekke grensen for hvilke typer lovbrudd som faller innunder forvaringsbestemmelsen. Selv om rettspraksis så langt viser at forvaring i overveiende grad brukes overfor de samme lovbruddene som i sin tid medførte sikring, ser vi nå at bestemmelsen søkes prøvd overfor lovbrytere som påtalemyndigheten mener tilhører såkalte organiserte kriminelle nettverk. Den 10. mars 2006 ble fire personer idømt forvaring i den såkalte NOKAS-saken..$^{53}$ Samtlige har anket dommen til lagmannsretten. Dersom disse forvaringsdommene blir stående, vil vi få en helt ny kategori forvaringsdømte. Dette vil stille kriminalomsorgen overfor nye utfordringer, spesielt med tanke på å tilrettelegge et innhold som kan imøtekomme det behovet man mener de har for endring, og i forhold til sikkerhet.

Et av de mest interessante forholdene å følge videre i forvaringsordningen er bruken av rettspsykiatrisk sakkyndige. Vil omfanget holde seg på det nivået som er i dag, eller vil flere forvaringsdommer bli avsagt på grunnlag av kun personundersøkelser? Likeledes, vil praksisen med å opprette rettspsykiatrisk sakkyndige ved prøveløslatelser befeste seg? Et spørsmål som melder seg i denne sammenhengen er hvorfor sakkyndige brukes i nesten like stor grad som under sikringsinstituttet? Er det av "gammel vane", "for sikkerhets skyld", "legitimering", eller er det andre momenter som spiller inn? Når vi ikke vet i hvilken grad retten tar hensyn til de sakkyndiges uttalelser når dom skal avsies, er disse spørsmålene svært relevante. Så langt kan det konkluderes med at man ikke har fått de kostnadsmessige innsparingene som det $\mathrm{i}$ forarbeidene ble forventet at mindre bruk av sakkyndige ville føre til.

Har vi innført livstidsstraff? Ja, i prinsippet har vi det fordi det ikke er noen grenser for hvor mange ganger tidsrammen kan forlenges. Om vi i realiteten har gjort det, vil praksisen i prøveløslatelsesspørsmålene avgjøre. Tar vi utgangspunkt i noen av de rettspsykiatriske erklæringene, ser vi at endringspotensialet spesielt for en del av de forvaringsdømte som ligger høyt i alder, forutses som lite (se også Johnsen 2003a). Hvis dette legges til grunn, og hvis endring skal være kriteriet for prøveløslatelse - noe kriminalomsorgen setter som vilkår - kan vi regne med at en del forvaringsdømte vil forbli i fengsel livet ut. Vi skal imidlertid være klar over at uttalelser om både endringspotensial og om endring har funnet sted inneholder ulik grad av skjønn, og det kan tenkes at man tar feil. 
Det kan også spørres om domfelte innenfor murene har mulighet til å oppnå den grad av endring som skal til for å kunne mestre en tilværelse i frihet. Retten fastslår i flere av prøveløslatelsessakene der kriminalomsorgen har gått imot løslatelse, at domfelte fremdeles har mer å hente på personlighetsmessig vekst og modning. Retten har likevel besluttet løslatelse idet de mener at innsatte har fătt den optimale nytten av det som kan tilbys innenfor fengselssystemet. Prøveløslatelse med tett oppfølging vil etter rettens oppfatning gi bedre forutsetninger for fortsatt endring, slik at domfelte etter hvert vil mestre tilværelsen i frihet på en bedre måte.

Et annet spørsmål som reiser seg vedrørende prøveløslatelse er: Hva gjør vi med utenlandske statsborgere som blir dømt til forvaring? Vil de bli prøveløslatt i Norge, eller vil de bli utvist når de har nådd minstetiden - eller kanskje tidsrammen - uavhengig av om de fremdeles blir ansett som "farlige"? Likeledes kan vi spørre: Hva med utenlandske statsborgere som blir overført til fortsatt gjennomføring av straffen i sine respektive hjemland? Den norske forvaringsordningen eksisterer ikke i samme form i noe annet land. Blir de overført til vanlig straffegjennomføring i fengsel, vil hensikten med å idømme dem forvaring i Norge falle bort.

Ennå har ikke domstolene behandlet noen saker om overføring av en person idømt tvungent psykisk helsevern til en forvaringsanstalt (se fotnote én). Når en slik sak eventuelt kommer, vil den trolig bli møtt med stor interesse. Det har på forhånd vært diskutert om denne bestemmelsen som gir anledning til å fengsle personer som på handlingstidspunktet er vurdert til å være skyldfrie, er i strid med Den europeiske menneskerettighetskonvensjonen. ${ }^{54}$ At en slik sak vil gå helt til Menneskerettighetsdomstolen, kan vi ikke se bort fra.

På bakgrunn av foreliggende praksis vil vi anta at de mest alvorlige sakene vil bli anket og avgjort i høyere rettsinstanser også i de nærmeste årene. At ankesakene i pådømmelsen av forvaring tar lang tid, må man nesten regne med i dagens rettssystem. Det er imidlertid kritikkverdig at ankesakene i spørsmålet om forlengelse av tidsrammen tar så lang tid at man går utover den opprinnelige sluttdatoen for tidsrammen. I slike tilfeller overføres fengslede forvaringsdømte til varetekt i påvente av at ankesaken blir avgjort, noe som er svært uheldig for den forvaringsdømte. For å unngå ekstra belastninger for de straffedømte er det viktig at både forlengelsessaker og konverteringsspørsmål blir avgjort før henholdsvis tidsrammen og sikringstiden løper ut.

Etter hvert som rettspraksis "setter seg" er det rimelig å anta at færre saker vil bli avgjort i Høyesterett. Så langt har vi ingen grunn til å tro at dette vil skje i overskuelig fremtid. Våre antakelser heller i retning av at forvaringens "kjerneområde" i stor grad vil gjelde de samme sakene som tidligere førte til deldommer. Endringene som ble gjort helt på tampen av revideringsprosessen (mulighet til å fastsette en tidsramme opptil 21 år og idømme forvaring ved første gangs lovbrudd), gjør at forvaring fremstår som lovens strengeste straff. Dette med- 
fører at forvaringsbestemmelsen også testes ut overfor andre typer lovbrudd, for eksempel ulike former for grov kriminalitet innenfor organiserte nettverk. Disse lovbruddene ville i de fleste tilfellene ha medført forholdsvis strenge fengselsstraffer hvor samfunnsbeskyttelsen kunne blitt ivaretatt ved lange fengselsopphold. En slik bruk av forvaringsinstituttet ligger langt unna den oprinnelige intensjonen med forvaring. Vårt spørgsmål er om dette er en ønskelig utvikling.

\section{Referanser}

Andenæs, Johs. (1989): Alminnelig strafferett, Oslo, Universitetsforlaget

Brev fra Justisdepartementet til Ila (1998): Iverksettelse av nytt saerreaksjonssystem - tilrettelegging av forholdene for bruk av Ila som "forvaringsanstalt", 15. juli 1998

Hennum, Ragnhild (2002): "Nye strafferettslige særreaksjoner", Materialisten, nr. $1 / 2$

Ila fengsel, forvarings - og sikringsanstalt (2002): Forvaring

Ila fengsel og sikringsanstalt (2001): Prosjektrapport forvaring, andre utkast

Innst.O. nr. 113 (2000-2001): Innstilling fra justiskomiteen om lov om erindringer i straffeloven og i enkelte andre lover (endrig og ikraftsetting av strafferettslige utilregnelighetsregler og særreaksjoner samt erindringer i straffeloven $§ 238$ og $\$ 239$

Innst.O. nr. 34 (1996-1997): Innstilling fra justiskomiteen om lov om endringer $i$ straffeloven m.v. (strafferettslige utilregnelighetsregler og sarreaksjoner)

Johnsen, Berit (2003a): "Forvaring i tall og tekst: Forvaringsstatistikk 1. januar 2002 - 28. februar 2003", Dokumentasjon og debatt, nr. 2, Oslo, Kriminalomsorgens utdanningssenter

Johnsen, Berit (2003b): Gjennomføringen av forvaringsstraffen og innholdet $i$ den - delrapport 1, Oslo, Kriminalomsorgens utdanningssenter, internrapport

Nilson, Pål (2005): "Bruk av rettspsykiatrisk sakkyndige i forvaringssaker”, Tidsskrift for strafferett, nr. 1

NOU 1990: 5 Strafferettslige utilregnelighetsregler og sarreaksjoner

NOU 1983: 57 Straffelovgivningen under omforming: Straffelovkommisjonens delutredning $I$

NOU 1974: 17 Strafferettslig utilregnelighet, strafferettslige sarreaksjoner

Ot.prp. nr. 46 (2000 - 2001): Om lov om endringer $i$ straffeloven og $i$ enkelte andre lover (endring og ikraftsetting av strafferettslige utilregnelighetsregler og sarreaksjoner samt endringer i straffeloven $\$ \$ 238$ og 239)

Ot.prp. nr. 87 (1993-1994): Om lov om endringer $i$ straffeloven m.v. (strafferettslige utilregnelighetsregler og sarreaksjoner) 
Rieber-Mohn, Georg Fr. (2003): "Forvaring - en strafferettslig særreaksjon”, Juristkontakt, nr. 4 og 5

Rundskriv nr. 4/2001: Rundskriv fra Riksadsvokaten: Utilregnelighetsregler og scerreaksjoner

Slettan, Svein og Øye, Toril (1997): Forbrytelse og straff. Larebok i strafferett, Oslo, Tano Aschehoug

Statistisk sentralbyrå: Kriminalstatistikk, perioden 1992-2001

Storvik, Birgitte Langset (2003): Straffegjennomføring etter lov av 18. mai 2001 $n r .21$, Kristiansand, Høyskoleforlaget

Syse, Aslak (1997): "Dømt til behandling - frikjent til fengsel. Nye strafferettslige ansvarsregler og særreaksjoner", Nytt $i$ strafferetten, nr. 1, s. 21-63

\section{Forkortelser}

Innst.O: Innstilling til Odelstinget (Stortingskomiteens forslag til vedtak)

Ot.prp: Odelstingsproposisjon

NOU: Norges offentlige utredninger

\section{Noter:}

I Norge er en person å anse som utilregnelig dersom han er psykotisk, psykisk utviklingshemmet i høy grad eller bevisstløs (med mindre bevisstløsheten er en følge av selvforskylt rus), jf. straffeloven $\S \S 44$ og 45.

Sikringsinstituttet er også opphevet i forhold til utilregnelige lovbrytere. Disse kan dømmes til særreaksjonene tvungent psykisk helsevern eller tvungen omsorg for psykisk utviklingshemmede. Unntaksvis åpner lovverket for at også utilregnelige lovbrytere kan ta opphold $\mathrm{i}$ en forvaringsanstalt under kriminalomsorgen. Dette gjelder personer som er dømt til tvungent psykisk helsevern der opphold på psykiatrisk institusjon ikke lenger anses riktig for domfelte, samtidig som gjentakelsesfaren vurderes til å være for stor til at reaksjonen kan opphøre.

NOU 1974:17.

NOU 1983:57.

NOU 1990:5.

Ot.prp. nr. 87 (1993-1994).

Innst.O. nr. 34 (1996-1997).

Ot.prp. nr. 46 (2000-2001) og Innst.O. nr. 113 (2000-2001).

For en mer detaljert gjennomgang av historikken, se Hennum 2002.

Lov av 17. januar $1997 \mathrm{nr} .11$.

Kombinasjon ubetinget fengsel og sikring, det såkalte dobbeltsporede system.

Kriminalstatistikk, Statistisk sentralbyrå.

Kilde. Kompis. Alle tall er fra 21. mars 2006.

Ot.prp. nr. 46 (2000-2001) s. 39.

Ot.prp. nr. 46 (2000-2001) s. 43.

5 Heierdal, Tone og Johansen, Cecilie (2005): "Miljøarbeid overfor forvaringsdømte på Bredtveit", foredrag på konferansen Om vi bare visste ..., Stjørdal, 9.-10. november, 2005.

16 Høyesterettsdom av 18. desember 2002 nr. 668.

17 Straffeloven $\S 39 \mathrm{c}$.

18 Ot.prp. nr. 87 (1993-1994) s. 111. 
19 NOU 1990:5 s. 84.

20 Straffeloven $\S 229$ første alternativ, jf. § 232.

21 Straffeloven $§ 195$ første ledd, første alternativ, og strl. $\S 212$ (nåværende $§ 201$ ).

22 Ot.prp. nr. $46(2000-2001)$ s. 31.

23 Ot.prp. nr. 87 (1993-1994) s. 111.

24 Innst.O. nr. 34 (1996-1997) kap 8.5, NOU:1990 s. 110.

25 Straffeloven $\S 39 \mathrm{~d}$.

26 Samtale Randi Rosenqvist, 22.november 2005.

27 Straffeprosessloven $\S 165$, jf. $\S 139$.

28 Rundskriv fra Riksadvokaten nr. 4/2001.

29 Se for eksempel Ot.prp. nr. 87 s. 89 og 103, og Innst.O. nr. 34 (1996-1997) kap. 12.

30 Høyesterettsdom av 18. desember 2002 nr. 668.

${ }_{31} \quad$ Høyesterettsdom av 18. desember $2002 \mathrm{nr} .663$.

32 Ot.prp. nr. 87 (1993-1994) s.112, NOU 1974:17 s. 97.

33 Høyesterettsdom av 18. desember $2002 \mathrm{nr} .668$ og høyesterettskjennelse av 18. desember 2002 nr. 915.

34 Innst.O. nr. 34 (1996-1997) kap. 8 s. 7.

35 Høyesterettsdom av 18. desember 2002 nr. 663.

36 I Høyesterettsdom av 27. juni 2002 er tidsrammen satt hele seks år høyere enn antatt alternativ fengselsstraff.

37 Innst.O. nr. 34 (1996-1997) s. 22.

38 Se spesielt Ot.prp. nr. 87 (1993-1994) kap. 8, Ot.prp. nr. 46 (2000-2001) kap. 5.5.

39 Forskrift om gjennomføring av særreaksjonen forvaring $\S 3$ av 5. mars 2004, gitt i medhold av straffeloven $\S 39 \mathrm{~h}$ og straffegjennomføringsloven $\S 5$.

40 Straffeloven $\S 39 \mathrm{f}$.

41 Straffeloven $\S 39 \mathrm{~g}$.

$42 \quad$ Straffeloven $\S 53 \mathrm{nr} .2$ til 5.

43 Straffeloven $\S 39 \mathrm{~g} \mathrm{og}$ forskrift om gjennomføring av særreaksjonen forvaring $\S 15$.

$44 \quad$ Nærmere om fastsettelse av vilkår ved prøveløslatelse, se Storvik 2003.

$45 \quad$ Innst.O. nr. 34 (1996-1997) kap. 8 s. 7.

46 NOU 1974: 17 s. 151, NOU 1990:5 s. 118.

47 Dom i Bergen tingrett av 10. mai 2005 og kjennelse i Borgarting lagmannsrett som stadfester dom i Oslo tingrett av 13. mai 2005.

48 I et brev fra Justisdepartementet til Ila fra 15. juli 1998 fremgår det at : ".. det er vanskelig å beregne antall personer som vil bli dømt til den nye særreaksjonen ....".

49 Ot.prp. nr. $46(2000-2001)$ s. 31.

so NOU 1990:5 s. 17 og 117.

51 Rundskriv fra Riksadvokaten nr. 4/2001.

52 Kilder: Kompis og kriminalstatistikken. Tallene er fra årenes begynnelse. Det kan hende at det i løpet av årene til tider har vært mer enn sju og mindre enn to fengslede kvinnelige sikringsdømte.

5313 personer sto tiltalt for delaktighet $\mathrm{i}$ en av norgeshistoriens groveste bankran (NOKAS tellesentral), der en politimann ble skutt og drept. Alle de tiltalte de ble dømt i tingretten.

$54 \quad$ Innst.O. nr. 34 (1996-1997) vedlegg 1 og Syse 1997 s. 57 flg.

Adresse:

Kriminalomsorgens utdanningssenter

Teisenveien 5

NO-0602 OSLO 